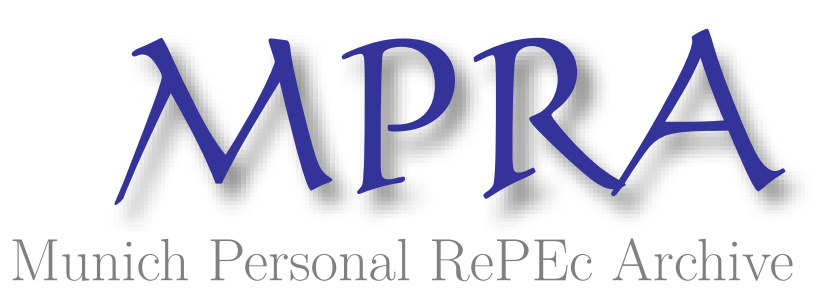

\title{
Real and Financial Shocks, Exchange Rate Regimes and the Probability of a Currency Crisis
}

Nakatani, Ryota

International Monetary Fund, Bank of Japan

24 October 2017

Online at https://mpra.ub.uni-muenchen.de/82186/

MPRA Paper No. 82186, posted 26 Oct 2017 01:40 UTC 


\title{
Real and Financial Shocks,
}

\section{Exchange Rate Regimes and the Probability of a Currency Crisis}

\author{
Ryota Nakatani \\ International Monetary Fund and Bank of Japan
}

E-mail: nakatani.ryouta@gmail.com

Address: 700 19th Street, N.W., Washington, D.C. 20431 


\begin{abstract}
We analyze the relationships among shocks, exchange rate regimes, and capital controls in relation to the probabilities of currency crises. Based on the theoretical model by Nakatani (2016, 2017a), we use panel data on 34 developing countries and apply a probit estimation. We find that both productivity shocks and country risk premium shocks trigger currency crises, whereas productivity shocks are important for severe currency crises. We also find that the effects of these shocks on the probability of a crisis are larger for floating exchange rate regimes and that capital controls mitigate the effects of productivity shocks in pegged regimes.
\end{abstract}

Keywords: Currency Crisis; Productivity Shock; Risk Premium Shock; Exchange

Rate Regimes; Capital Control; Probit Model

JEL Classification: E5; F3; F41; G01 


\section{Introduction}

Preventing financial crises has become one of the top priorities of policymakers in many countries, especially in light of the recent global financial crisis. The most frequent type of financial crisis in modern history is a currency crisis. Many economists and scholars in academia, international financial institutions and central banks have analyzed the mechanisms of currency crises both theoretically and empirically. In theory, the main areas of focus were inconsistent macroeconomic policies, a self-fulfilling prophecy caused by the interaction between policymakers and investors, and financial frictions and regulations as causes of currency crises. On the empirical side, many policymakers attempted to establish Early Warning Indicators to predict a future potential crisis.

However, despite the abundant theoretical and empirical literature, almost no literature has analyzed what types of shocks triggered currency crises. As we will discuss in greater detail in the literature review section, in most theories, it is assumed that a certain type of shock, such as a financial shock or a real shock, can lead to a currency crisis. For example, Nakatani $(2016,2017 \mathrm{a})$ recently developed a model in which a productivity shock in the real sector and/or a shock to a country's risk premium can lead to a currency crisis. Despite this theoretical background, the question of which types of shocks led to past currency crises is purely an empirical issue, which has thus far only been analyzed by Nakatani (2017b). Nakatani (2017b) analyzed the effects of both productivity shocks and risk premium shocks on exchange rate dynamics, but he did not analyze the effects on the probability of a crisis. For this reason, in this article, we are the first to 
analyze the effects of financial and real shocks on the probability of a currency crisis using a probit estimation technique.

We elucidate the currency crisis mechanism empirically from the perspectives of policymakers by asking and answering three key questions. First, the types of shocks that can increase the probability of a currency crisis and its severity are investigated. In other words, this is the first empirical paper that studies the effects of two (real and financial) shocks on crisis probability. It is important to study the types of shocks that trigger currency crises and increase the severity of the situation because such knowledge will have invaluable implications for economists and policymakers who formulate international macroeconomic policies to prevent such crises. If financial shocks are important triggering factors of the crises, policymakers need to concentrate on developing financial supervisions and macroprudential policies. In contrast, if productivity shocks appear to be more important, they need to focus more on macroeconomic and industrial policies (e.g., product market regulations, labor market reforms, etc.) that can influence the real side of the economy. This paper addresses the question empirically based on the theoretical currency crisis model developed by Nakatani (2014, 2016, 2017a), which has several advantages over other types of models, as we will elaborate later. Following this model, we focus on two types of shocks—real shocks and financial shocks - using the data and analytical framework developed by Nakatani (2017b). We aim to contribute to the existing literature through an analysis of the effects of these shocks on the probability of a currency crisis, which is necessary because exclusion of the shocks from the independent variables can generate an omitted variable bias on the estimated coefficients. 
In terms of data and methodology, we use unbalanced annual panel data comprising 34 emerging market and developing countries, and we apply a panel probit model. Our results suggest that both productivity shocks in the real sector and shocks to a country's risk premium in the financial markets affect the probability of a currency crisis occurring, while productivity shocks appear to be more important for severe currency crises.

Next, we further investigate the relationship between exchange rate policies and shock-induced crisis probability. Policymakers have been keen to understand the effectiveness of policy instruments to combat currency crises. Most literature has analyzed the effects of monetary policy responses to currency crises. For instance, Nakatani (2017b) used panel data on developing countries and found that an increase in the policy interest rate is associated with an appreciation of the domestic currency. However, an interest rate defense is not the only policy tool that can be used to manage currency crises. If a shock triggers the currency crisis, different exchange rate policies can have different effects on a currency crisis. For example, if the country has a floating exchange rate regime, the exchange rate can fluctuate freely to respond to various shocks. Therefore, the floating exchange rate regime might be more prone to experience large currency fluctuations and hence to experience a currency crisis as the nominal exchange rate responds quickly to the real shocks. In this context, this paper also studies how different exchange rate policies have different shock effects on the probability of a crisis. Thus, the second question is, "Does each shock have a different probability of a currency crisis if the country has a different exchange rate policy?" Our results show that the effects of these shocks are larger for floating 
exchange rate regimes than for pegged ones. This might be a potential explanation for why some empirical studies have found that floating exchange rate regimes are more prone to experiencing currency crises.

Moreover, we also analyze the role of capital control policies on the shocks. As a famous macroeconomic policy trilemma suggests, the monetary policy, exchange rate policy, and capital controls are the three main international macroeconomic policy tools to manage international financial crises, but each of these policies is constrained by the other remaining policies. ${ }^{1}$ In essence, capital controls can diminish the negative feedback effects resulting from volatile speculative capital. Erten and Ocampo (2017) found that capital account restrictions reduce foreign exchange pressure and contribute to greater macroeconomic stability; in particular, increasing the restrictiveness of capital controls in the run-up to the crisis moderates the growth decline, thus enhancing the crisis resilience. In other words, rapid financial and capital account liberalization without regulatory institutions and a safety net exposes countries to the risks of a crisis, as suggested by Stiglitz (1999). In the context of the currency crises model, Ozkan and Sutherland (1995) and Agénor et al. (1992) theoretically demonstrated that capital controls (or Tobin tax) can defer the occurrence of currency crises. ${ }^{2}$ In our empirical setting, we study the role of capital controls to mitigate the effects of shocks that lead to currency crises, and we discuss our results from the perspective of the policy trilemma. Thus, the third question of this paper is, "Do capital control policies have different effects on different types of shocks that trigger currency

${ }^{1}$ See discussion on the trilemma by Obstfeld et al. (2017).

${ }^{2}$ See De Grauwe (2000) for further discussions on Tobin tax and capital controls. 
crises?" In summary, we diagnose currency crises from the viewpoint of shocks and their relationship with exchange rates and capital control policies.

The organizational structure of this paper is as follows. In the next section, we review the literature on three generations of currency crisis models and the empirical literature on the probability of currency crises. Then, we explain our empirical methodology and data and present our baseline empirical results. We further demonstrate robustness checks to support our main results and investigate the relationships among different shocks, exchange rate regimes and capital controls. Finally, we conclude our results and derive policy implications and future potential research topics.

\section{Literature Review}

The theoretical currency crises models are classified into three generations. ${ }^{3}$ First-generation models analyze a fixed exchange rate regime with an expanding fiscal policy, which is monetized by the monetary authority (Krugman 1979). This inconsistent macroeconomic policy mix leads to a currency crisis, which is foreseen a priori without any shock. In second-generation models, a central bank has its own objective function and minimizes the loss function (Obstfeld 1996). This type of model incorporates the strategic interaction between a central bank and international investors and exhibits a self-fulfilling prophecy (Cheli and Posta 2007). In second-generation models, an expectational shock, such as a shift in investors' expectations, which can be captured as

\footnotetext{
${ }^{3}$ Nakatani (2017c) recently invented a new type of balance of payments crisis model in which a commodity price shock causes foreign exchange shortages.
} 
a risk premium shock, triggers the currency crisis. Third-generation models, which focus on financial friction and banking problems, include various types of models. For example, an external shock in the international financial markets increases a country's risk premium, which in turn worsens the balance sheets of firms and leads to a currency crisis (Céspedes et al. 2004). Other models show that not only financial shocks but also productivity shocks can trigger currency crises through deteriorating balance sheets of firms (Aghion et al. 2001; Nakatani 2017a) or commercial banks (Nakatani 2016). Similarly, a production shock can cause a currency crisis induced by liquidity problems under binding international and domestic collateral constraints (Caballero and Krishnamurthy 2001). Although we do not focus on banking crises in this paper, shocks to depositors' preferences may cause simultaneous bank runs and currency crises (Chang and Velasco 2001). Finally, the introduction of governments' and/or international financial institutions' implicit or explicit guarantees on lending can cause an over-borrowing syndrome and a moral hazard problem that results in currency crises (McKinnon and Pill 1997; Dooley 2000; Dekle and Kletzer 2002; Schneider and Tornell 2004).

As we can see from the literature cited above, major shocks encompassed by various theories include productivity (or production) shocks and shocks in the financial markets (e.g., Aghion et al. 2001; Caballero and Krishnamurthy 2001; Nakatani 2016, 2017a). ${ }^{4}$ The currency crisis model developed by Nakatani $(2016,2017 a)$ is the most suitable model for this analysis because it can

\footnotetext{
${ }^{4}$ Among these theories, it is nearly impossible to consider government guarantees to be a triggering shock that results in a currency crisis because it always takes several years for the over-borrowing syndrome to result in the crisis.
} 
analyze several types of shocks and includes features of all three generational types of currency crisis models. Furthermore, this model allows us to analyze both fixed and flexible exchange rate regimes. For these reasons, we use the model developed by Nakatani (2016, 2017a) to empirically analyze the effects of productivity shocks and financial shocks, i.e., shocks to a country's risk premium. ${ }^{5}$ In other words, most of our explanatory variables are derived from a specific type of theoretical model (Nakatani 2016, 2017a); hence, the specification of the model that we estimate is based on strong theoretical underpinnings.

The probability of a currency crisis has been analyzed in the empirical literature. Studies have used a probit model to estimate the probability of currency crises or currency crashes (Eichengreen et al. 1996: Frankel and Rose 1996; Berg and Pattillo 1999; Kruger et al. 2000; Komulainen and Lukkarila 2003; Frankel 2005; Licchetta 2011; Furceri et al. 2012; Zhao et al. 2014). ${ }^{6}$ Before examining the empirical literature, it is worth distinguishing between "currency crises" and "currency crashes" because these are two different concepts that are frequently confused. A currency crash is defined when the nominal exchange rate depreciates by a certain threshold (e.g., by $15 \%$ ). This is the case when a country experiences high inflation or when a successful speculative attack occurs. By contrast, a currency crisis is a situation in which a country faces a balance of payment crisis either because of a large loss of foreign reserves and/or a large currency

\footnotetext{
${ }^{5}$ Another way to analyze the effects of shocks on the economy is to use a simulation method. For example, using a simulated dynamic general equilibrium model, Robert (2005) showed that both an interest rate shock and a productivity shock were causes of the Korean crisis.

${ }^{6}$ Although some studies use a logit model, the interpretation of the results is not straightforward, as this is not a probability of crises (Kumar et al. 2002).
} 
depreciation. In other words, currency crises include cases of both successful and unsuccessful speculative attacks on a domestic currency. Therefore, we can think of currency crashes as a subset of currency crises.

Some studies have analyzed currency crashes. Using panel data from 20 industrial countries, Eichengreen et al. (1996) included a dummy variable for a currency crash in foreign countries in the probit model, finding evidence of contagion. Frankel and Rose (1996) used data with a broader coverage of sample countries and found that higher debt and lower international reserves relative to imports are associated with a higher probability of currency crashes. Frankel (2005) also found that higher import coverage of international reserves is associated with a lower probability of currency crashes. Moreover, according to the probit estimation results presented by Furceri et al. (2012), international reserves and short-term interest rates are relevant for the probability of currency crashes. Zhao et al. (2014) found that real exchange rate overvaluation and international reserves are important determinants of currency crashes for fixed exchange rate regimes, whereas credit growth is important for floating regimes.

On the other hand, empirical studies on currency crises have found the following evidence. Using data for 20 developing countries, Kruger et al. (2000) found that real exchange rate overvaluation and a dummy variable for a currency crisis in a foreign country had statistically significant effects on the probability of currency crises. Analyzing the data on 31 emerging market countries, Komulainen and Lukkarila (2003) found that the foreign debt of private companies and banks provides a good explanation of currency crises. Licchetta (2011) found that the debt-to-GDP 
ratio, real exchange rate overvaluation, and real GDP growth have an influence on the probability of currency crises.

However, none of these empirical studies have analyzed the effects of shocks on the probability of currency crises based on a specific theoretical model or their relationship with exchange rate regimes and capital account restrictions. Thus, this is the first article to analyze the effects of shocks on the probability of currency crises and their relationship with exchange rate and capital control regimes.

\section{Methodology and Data}

This paper uses the model developed by Nakatani $(2016,2017 a)$ to analyze the effects of country risk premium shocks and productivity shocks on the probability of currency crises. The model shows that the nominal exchange rate and output are determined by the intersection of two curves, the Wealth curve and the IPLM curve, which are depicted in two dimensions, i.e., output on the horizontal axis and the nominal exchange rate on the vertical axis. The Wealth curve is characterized by the behavior of firms and is downward sloping and concave. The model predicts that if there is a negative productivity shock, the Wealth curve shifts to the left, which causes the possibility of currency crisis equilibrium. A relevant economic intuition is that the unanticipated negative productivity shock reduces output, profits, retained earnings, net worth and the investment of firms, thus resulting in extremely lower output and a corresponding lower need for money (i.e., depreciation of domestic currency) in the next period. By contrast, the IPLM curve is 
characterized by a central bank's behavior and money market equilibrium; it is also downward sloping but is convex. If there is a positive country risk premium shock, the IPLM curve shifts upward, which also generates the possibility of currency crisis equilibrium. Economic intuition holds that an abrupt deterioration in investors' perceptions about a country's gross foreign debt can lead to an increase in the country's risk premium, which in turn induces depreciation of the national currency because of the interest parity condition. Thus, in our empirical analysis, the main explanatory variables are these two shocks, i.e., the productivity shock (W-shock) and the shock to the country's risk premium (IPLM-shock). Although we do not analyze contagion in this paper, it is well noted that a contagion effect is captured in the IPLM-shock. In addition to these two shocks, we also include the interest rate policy variable in the explanatory variables because this may also affect the possibility of currency crisis equilibrium. Furthermore, following the empirical literature, we also include four control variables: exchange rate overvaluation, deviation of GDP growth, the ratio of short-term external debt to GDP, and international reserves to imports. Although the key feature of the model developed by Nakatani (2016, 2017a) is foreign (currency) debt and although this model can also include key factors of the first-generation model (level of international reserves) and second-generation model (overvaluation of exchange rates), these variables are neither triggering factors nor shocks in this theoretical model. Moreover, the purpose of this paper is to perform an econometrical analysis to capture the effects of shocks on the probability of a currency crisis based on the specific theoretical currency crisis model rather than to look for underlying factors that can lead to currency crises by including as many explanatory variables as 
possible, which has been characteristic of the existing empirical literature. ${ }^{7}$ The regression equation to determine the relationship between several shocks and the probability of a currency crisis is defined as follows:

$$
\operatorname{Pr}(y=1 \mid x)=\Phi\left(x^{\prime} \beta\right)+\varepsilon
$$

where $\operatorname{Pr}$ is probability, $y$ is a dummy variable that is unity if a currency crisis occurs and zero if not, $x$ is the set of independent variables mentioned above, $\Phi$ is the normal cumulative distribution, $\beta$ is a vector of maximum likelihood estimate, and $\varepsilon$ is an error term. Currency crises dates are determined by the Exchange Market Pressure Index (EMPI), defined as a weighted average of monthly percent real effective exchange rate depreciation and monthly percent international reserve losses with weights such that the two components equal the sample volatility, with a 24-month window to avoid capturing the same crisis (Kaminsky and Reinhart 1999). Both monthly series are taken from the International Monetary Fund (IMF)'s International Financial Statistics. ${ }^{8}$ Here, we examine two different criteria for defining a currency crisis. A "standard currency crisis" year is defined when EMPI exceeds the mean plus two country-specific standard deviations, whereas a "severe currency crisis" year is defined when EMPI exceeds the mean plus three country-specific standard deviations. We study whether the results differ across different definitions of currency crises.

\footnotetext{
${ }^{7}$ This primarily relates to Early Warning Indicators (e.g., Salvatore 1999; Alvarez-Plata and Schrooten 2004; Beckman et al. 2006).

${ }^{8}$ If a monthly real exchange rate variable is missing in this database, the data are taken from the Bank for International Settlements' monthly real exchange rates.
} 
The sample in this study covers 34 countries from 1980 to 2011 (Appendix). ${ }^{9}$ The detailed construction and sources of the data and summary statistics for each variable used in this analysis are presented in Nakatani (2017b).

\section{Baseline Estimation Results}

We are interested in the effects of real and financial shocks on the probability of a currency crisis. In the theoretical model, two types of shocks can trigger currency crises. One is a shock to a country's risk premium, which is displayed as the IPLM-shock in this model and in the table. The other type of shock is a productivity shock, which is referred to as the W-shock. According to the baseline estimation results shown in Table 1, both types of shocks are found to be statistically significant at the $5 \%$ level for standard currency crises. The signs of coefficients on both variables are consistent with the theory by Nakatani (2016, 2017a). Specifically, an increase in the country's risk premium is associated with a higher probability of a currency crisis, whereas a negative productivity shock is also associated with a higher probability of a crisis. By contrast, the results presented in the second column of Table 1 suggest that only the W-shock is statistically significant for severe currency crises, and the significance level increases from $5 \%$ to $1 \%$. In other words, negative productivity shocks are a key triggering factor for severe currency crises. Furthermore, a statistically significant positive coefficient on the deviation of GDP growth implies that a severe

\footnotetext{
${ }^{9}$ Since we include both IPLM-shock and W-shock at the same time in the estimation, the number of countries is 34. By contrast, Nakatani (2017b) used a sample of countries that had at least one type of shock; hence, the number of countries was 51.
} 
crisis is likely to occur when the economy is booming. Combining these results, we can interpret the main findings as follows. If an economy is deviating from the trend growth rates and then experiences a negative productivity shock, the country is likely to experience a severe currency crisis. Furthermore, there is weak evidence for the notion that a country can avoid such a severe crisis if it has enough import coverage of international reserves (i.e., the coefficient on the ratio of reserves to imports is negative and statistically significant at the $10 \%$ level). Other control variables in the table are not statistically significant.

Table 1: Results of Baseline Panel Probit Model

\begin{tabular}{lcc}
\hline \multicolumn{1}{c}{ Crisis Definition } & $\begin{array}{c}\text { Standard Currency Crisis } \\
\text { (2 std. dev. of EMPI })\end{array}$ & $\begin{array}{c}\text { Severe Currency Crisis } \\
(3 \text { std. dev. of EMPI) }\end{array}$ \\
\hline Interest Rate Policy & 0.0008 & 0.0006 \\
& $(0.0006)$ & $(0.0004)$ \\
IPLM-Shock & $0.0007^{* *}$ & 0.0003 \\
W-Shock & $(0.0003)$ & $(0.0003)$ \\
& $-0.0095^{* *}$ & $-0.0093^{* * *}$ \\
Short-term External Debt / GDP & $(0.0037)$ & $(0.0028)$ \\
& -0.0041 & -0.0023 \\
Deviation GDP Growth & $(0.0026)$ & $(0.0020)$ \\
\hline \multirow{2}{*}{ Exchange Rate Overvaluation } & 0.0054 & $0.0087^{* *}$ \\
& $(0.0043)$ & $(0.0034)$ \\
Foreign Reserves / Imports & 0.0016 & 0.0009 \\
& $(0.0017)$ & $(0.0012)$ \\
\hline
\end{tabular}

Number of Observations 551 551

Notes: Average marginal effects are reported. The significance level of the variables is indicated by $*(10 \%)$, $* *(5 \%)$ and $* * *(1 \%)$. Standard errors are in parentheses. 


\section{Robustness Checks: Exchange Rate Regimes and Capital Controls}

The sample countries and period of the data in this article include different exchange rate regimes because the model developed by Nakatani $(2016,2017$ a) can analyze both floating and pegged exchange rate regimes. However, in practice, the effects of shocks and interest rate policy may differ across exchange rate regimes as we have discussed in the introduction. In fact, several empirical studies have analyzed the effects of exchange rate regimes on currency crises because the different exchange rate regimes may have different probabilities of a currency crisis (e.g., Haile and Pozo 2006; Esaka 2010; Ghosh et al. 2015; Combes et al. 2016). For example, Esaka (2010) concluded that pegged exchange rate regimes are less prone to currency crises. This different probability of currency crisis across exchange rate regimes can be attributed to the different effects of shocks across exchange rate regimes. To analyze this issue, we use a subset of the data with comparable exchange rate regimes. We use the following two classifications that are common in the literature. The first is the de facto exchange rate regime classification by Ilzetzki et al. (2017). The second is the de jure exchange rate regime classification by the IMF. We classify exchange rate regimes into two general categories: floating and pegged regimes (and not into intermediate regimes because we are not aiming to analyze bipolar views in this paper). Following Klein and Shambaugh (2008), pegged regimes include currency board, conventional peg and stabilized arrangement; the others are floating exchange rate regimes. For the de jure classification, as most of the data are de jure floating exchange rate regimes, the results shown exclude de jure pegged 
regimes.

Table 2 presents the results based on the de facto exchange rate regime classification. The results for de facto floating regimes are as follows. First, we see that both IPLM-shock and W-shock affect the probability of a standard currency crisis, but only W-shock is statistically significant for a severe currency crisis in de facto floating regimes. This observation, that both real and financial shocks trigger currency crises, is consistent with the Nakatani $(2016,2017 \mathrm{a})$ model and agrees with our baseline regression results, although the coefficients on $\mathrm{W}$-shock are somewhat larger than those in the baseline. Thus, if a country has a de facto floating exchange rate regime, the triggering effect of the shock becomes somewhat larger. Additionally, our finding that the $\mathrm{W}$-shock is a cause of severe currency crisis for de facto floating regimes agrees with the baseline estimation. In addition to these shocks, the overvaluation of exchange rates is statistically significant at the $5 \%$ level for both definitions of currency crises in de facto floating regimes. The sign and statistical significance of the coefficient on the deviation of GDP growth is close to the results in Table 1. By contrast, in de facto pegged regimes, only the W-shock is statistically significant at the 5\% level for severe currency crises. Interestingly, an interest rate hike is associated with a higher probability of currency crisis for both definitions of currency crises in de facto pegged regimes. A possible interpretation of this result is that if raising interest rates is believed to signal weak fundamentals or panic at the monetary authorities, then it will evoke more speculative attacks and lead to a currency crisis (Drazen 2003). In fact, the sign of the coefficients on the exchange rate overvaluation supports this view. In other words, in de facto pegged regimes, 
the monetary authority raises the interest rate, which can be perceived as a bad signal for investors and can lead to large currency depreciation (and/or loss of reserves). Pegged regimes can be successful only if they are supported by the credible commitment of monetary (and fiscal) policy in combination with a strong financial system (Mussa 1999).

Table 2: Results Based on De Facto Exchange Rate Regime

\begin{tabular}{|c|c|c|c|c|}
\hline Exchange Rate Regime & De Facto Floating & De Facto Floating & De Facto Pegged & De Facto Pegged \\
\hline Crisis Definition & $\begin{array}{c}\text { Standard Currency } \\
\text { Crisis } \\
\text { (2 std.dev. of EMPI) }\end{array}$ & $\begin{array}{l}\text { Severe Currency Crisis } \\
\text { (3 std.dev. of EMPI) }\end{array}$ & $\begin{array}{c}\text { Standard Currency } \\
\text { Crisis } \\
\text { (2 std.dev. of EMPI) }\end{array}$ & $\begin{array}{c}\text { Severe Currency Crisis } \\
\text { (3 std.dev. of EMPI) }\end{array}$ \\
\hline Interest Rate Policy & $\begin{array}{c}0.0009 \\
(0.0006)\end{array}$ & $\begin{array}{c}0.0006 \\
(0.0004)\end{array}$ & $\begin{array}{l}0.0205^{* *} \\
(0.0101)\end{array}$ & $\begin{array}{c}0.0198 * * \\
(0.0080)\end{array}$ \\
\hline IPLM-Shock & $\begin{array}{c}0.0008 * * \\
(0.0004)\end{array}$ & $\begin{array}{c}0.0004 \\
(0.0003)\end{array}$ & $\begin{array}{c}0.0002 \\
(0.0017)\end{array}$ & $\begin{array}{c}0.0004 \\
(0.0010)\end{array}$ \\
\hline W-Shock & $\begin{array}{c}-0.0134 * * \\
(0.0051)\end{array}$ & $\begin{array}{c}-0.0121^{* * *} \\
(0.0036)\end{array}$ & $\begin{array}{l}-0.0081 \\
(0.0054)\end{array}$ & $\begin{array}{c}-0.0094 * * \\
(0.0044)\end{array}$ \\
\hline Short-term External Debt / GDP & $\begin{array}{l}-0.0048 \\
(0.0041)\end{array}$ & $\begin{array}{l}-0.0024 \\
(0.0030)\end{array}$ & $\begin{array}{l}-0.0010 \\
(0.0030)\end{array}$ & $\begin{array}{c}0.0003 \\
(0.0021)\end{array}$ \\
\hline Deviation GDP Growth & $\begin{array}{c}0.0066 \\
(0.0057)\end{array}$ & $\begin{array}{l}0.0079 * \\
(0.0042)\end{array}$ & $\begin{array}{c}0.0051 \\
(0.0056)\end{array}$ & $\begin{array}{c}0.0097 * * \\
(0.0047)\end{array}$ \\
\hline Exchange Rate Overvaluation & $\begin{array}{c}0.0054 * * \\
(0.0025)\end{array}$ & $\begin{array}{c}0.0044 * * \\
(0.0017)\end{array}$ & $\begin{array}{c}-0.0060^{* *} \\
(0.0029)\end{array}$ & $\begin{array}{c}-0.0072 * * * \\
(0.0027)\end{array}$ \\
\hline Foreign Reserves / Imports & $\begin{array}{l}-0.0434 \\
(0.0502)\end{array}$ & $\begin{array}{l}-0.0745 \\
(0.0464)\end{array}$ & $\begin{array}{l}-0.0571 \\
(0.0590)\end{array}$ & $\begin{array}{l}-0.0222 \\
(0.0393)\end{array}$ \\
\hline Number of Observations & 350 & 350 & 201 & 201 \\
\hline
\end{tabular}

Notes: Average marginal effects are reported. The significance level of the variables is indicated by $*(10 \%)$, $* *(5 \%)$ and $* * *(1 \%)$. Standard errors are in parentheses.

We also found an interesting comparison between floating and pegged exchange rate regimes. 
If we compare the coefficients on IPLM-shock and W-shock between the de facto floating and pegged regimes for the same definition of a currency crisis, the coefficients are always larger for floating regimes. This implies that the floating exchange rate regimes are more vulnerable to shocks that trigger currency crises. This can potentially explain why some empirical studies have found that countries that adopt floating exchange rate regimes are more prone to currency crises.

Table 3: Results Based on De Jure Exchange Rate Regime

\begin{tabular}{lcc}
\hline \multicolumn{1}{c}{ Exchange Rate Regime } & De Jure Floating & De Jure Floating \\
\hline \multicolumn{1}{c}{ Crisis Definition } & $\begin{array}{c}\text { Standard Currency Crisis } \\
\text { (2 std. dev. of EMPI) }\end{array}$ & $\begin{array}{c}\text { Severe Currency Crisis } \\
\text { (3 std. dev. of EMPI) }\end{array}$ \\
\hline Interest Rate Policy & 0.0009 & $0.0006^{*}$ \\
& $(0.0006)$ & $(0.0004)$ \\
\hline IPLM-Shock & $0.0008^{* *}$ & 0.0003 \\
& $(0.0003)$ & $(0.0003)$ \\
W-Shock & $-0.0098^{* *}$ & $-0.0091 * * *$ \\
Short-term External Debt / GDP & $(0.0038)$ & $(0.0029)$ \\
\hline Deviation GDP Growth & -0.0045 & -0.0022 \\
\hline Exchange Rate Overvaluation & $(0.0028)$ & $(0.0018)$ \\
\hline Foreign Reserves / Imports & 0.0058 & $0.0086^{* *}$ \\
\hline Number of Observations & $(0.0044)$ & $(0.0035)$ \\
\hline
\end{tabular}

Notes: Average marginal effects are reported. The significance level of the variables is indicated by $*(10 \%)$, $* *(5 \%)$ and $* * *(1 \%)$. Standard errors are in parentheses. 
Furthermore, we also present the results based on de jure exchange rate regimes in Table 3. Note that most of our samples are de jure floating regimes; hence, we can only show the results for this category. We found that the results are almost the same as the baseline regression presented in Table 1, and we can therefore conclude that our empirical results are robust to de jure floating exchange rate regimes. In summary, both IPLM-shock and W-shock can cause currency crises, while $\mathrm{W}$-shock is an important trigger for severe currency crises for de jure floating exchange rate regimes.

Finally, we further analyze the roles of capital controls in the presence of shocks because the famous international macroeconomic policy trilemma suggests that capital account restrictions also influence the economic system, in addition to exchange rate policies and monetary policies. In Table 4, we show the results, including the interaction term of each shock and the capital control dummy constructed by Nakatani (2017b). The results indicate that in the presence of capital controls, countries in de facto floating exchange rate regimes tend to have a higher probability of a severe currency crisis when they experience an IPLM-shock. This result is consistent with Esaka (2010, 2013), who found that floating exchange rate regimes significantly increase the probability of currency crisis compared with pegged ones under capital controls. By contrast, the coefficients on the interaction term of the $\mathrm{W}$-shock and capital control are always positive and statistically significant at the $5 \%$ level for standard currency crises and at the $10 \%$ level for severe currency crises in de facto pegged exchange rate regimes. This implies that capital controls can mitigate the effects of the $\mathrm{W}$-shock on the probability of currency crises in de facto pegged exchange rate 
regimes. This finding is consistent with the conventional view that pegged regimes under liberalized capital accounts increase the risk of currency crises (Radelet and Sachs 1998). The results for the other variables do not change substantially from those in Table 2.

Table 4: Results Based on De Facto Exchange Rate Regime and Capital Control

\begin{tabular}{|c|c|c|c|c|}
\hline Exchange Rate Regime & De Facto Floating & De Facto Floating & De Facto Pegged & De Facto Pegged \\
\hline Crisis Definition & $\begin{array}{c}\text { Standard Currency } \\
\text { Crisis } \\
\text { (2 std.dev. of EMPI) }\end{array}$ & $\begin{array}{c}\text { Severe Currency Crisis } \\
\text { (3 std.dev. of EMPI) }\end{array}$ & $\begin{array}{c}\text { Standard Currency } \\
\text { Crisis } \\
\text { (2 std.dev. of EMPI) }\end{array}$ & $\begin{array}{c}\text { Severe Currency Crisis } \\
\text { (3 std.dev. of EMPI) }\end{array}$ \\
\hline Interest Rate Policy & $\begin{array}{c}0.0007 \\
(0.0006)\end{array}$ & $\begin{array}{c}0.0003 \\
(0.0004)\end{array}$ & $\begin{array}{l}0.0158^{*} \\
(0.0091)\end{array}$ & $\begin{array}{l}0.0148 * * \\
(0.0069)\end{array}$ \\
\hline IPLM-Shock & $\begin{array}{l}0.0007 * * \\
(0.0004)\end{array}$ & $\begin{array}{c}0.0002 \\
(0.0004)\end{array}$ & $\begin{array}{c}0.0001 \\
(0.0023)\end{array}$ & $\begin{array}{c}0.0003 \\
(0.0012)\end{array}$ \\
\hline W-Shock & $\begin{array}{l}-0.0137^{*} \\
(0.0080)\end{array}$ & $\begin{array}{c}-0.0178^{* * * *} \\
(0.0059)\end{array}$ & $\begin{array}{c}-0.0390 * * \\
(0.0171)\end{array}$ & $\begin{array}{c}-0.0277 * * \\
(0.0137)\end{array}$ \\
\hline IPLM-Shock $\times$ Capital Control & $\begin{array}{c}0.0022 \\
(0.0021)\end{array}$ & $\begin{array}{l}0.0028^{* *} \\
(0.0014)\end{array}$ & $\begin{array}{c}0.0000 \\
(0.0063)\end{array}$ & $\begin{array}{c}0.0020 \\
(0.0058)\end{array}$ \\
\hline W-Shock $\times$ Capital Control & $\begin{array}{c}0.0005 \\
(0.0087)\end{array}$ & $\begin{array}{c}0.0079 \\
(0.0062)\end{array}$ & $\begin{array}{c}0.0328 * * \\
(0.0160)\end{array}$ & $\begin{array}{l}0.0206^{*} \\
(0.0125)\end{array}$ \\
\hline Short-term External Debt / GDP & $\begin{array}{l}-0.0044 \\
(0.0043)\end{array}$ & $\begin{array}{l}-0.0021 \\
(0.0032)\end{array}$ & $\begin{array}{l}-0.0012 \\
(0.0027)\end{array}$ & $\begin{array}{c}0.0003 \\
(0.0018)\end{array}$ \\
\hline Deviation GDP Growth & $\begin{array}{c}0.0073 \\
(0.0059)\end{array}$ & $\begin{array}{c}0.0095 * * \\
(0.0043)\end{array}$ & $\begin{array}{c}0.0070 \\
(0.0055)\end{array}$ & $\begin{array}{c}0.0102 * * \\
(0.0049)\end{array}$ \\
\hline Exchange Rate Overvaluation & $\begin{array}{l}0.0054 * * \\
(0.0025)\end{array}$ & $\begin{array}{l}0.0040 * * \\
(0.0017)\end{array}$ & $\begin{array}{l}-0.0057^{* *} \\
(0.0028)\end{array}$ & $\begin{array}{c}-0.0065^{* * * *} \\
(0.0025)\end{array}$ \\
\hline Foreign Reserves / Imports & $\begin{array}{l}-0.0465 \\
(0.0506)\end{array}$ & $\begin{array}{l}-0.0796^{*} \\
(0.0455)\end{array}$ & $\begin{array}{l}-0.0737 \\
(0.0620)\end{array}$ & $\begin{array}{l}-0.0280 \\
(0.0382)\end{array}$ \\
\hline Number of Observations & 350 & 350 & 196 & 196 \\
\hline
\end{tabular}

Notes: Average marginal effects are reported. The significance levels of the variables are indicated by *(10\%), $* *(5 \%)$ and $* * *(1 \%)$. Standard errors are in parentheses. 


\section{Conclusion and Policy Implications}

Which shock triggers a currency crisis: a productivity shock in the real sector or a country risk premium shock in the financial markets? Which shock leads to a more severe currency crisis? Does each shock have a different probability of a currency crisis if the country has a different exchange rate policy? Do capital control policies have different effects on different types of shocks that trigger currency crises? We have answered these questions empirically by using panel data from emerging market and developing countries and applying a probit model. It is important to answer these questions empirically because if different shocks have different probabilities of currency crises, we must consider the source of shocks when we formulate macroeconomic policies to prevent crises.

Our results can be summarized by the following five key points. First, we found that both country risk premium shocks and productivity shocks can trigger currency crises. Second, productivity shocks are found to be important triggers for severe currency crises, and this result is robust to exchange rate regimes. These first two key results produce the following main policy implications; policymakers need to focus not only on the financial supervision and macroprudential policies to prepare a safety net against financial shocks but also on economic and industrial policies to avoid severe currency crises because we found that real (productivity) shocks trigger severe crises. For instance, as we argued in the introduction, various market regulations and structural reforms can influence innovations, as well as exits and entries of firms, and thereby 
change productivity dynamics. Third, we found that the floating exchange rate regimes are more vulnerable to shocks that trigger currency crises. This finding is consistent with the existing empirical literature, which found floating exchange rate regimes are more prone to experiencing currency crises. Fourth, from the perspective of monetary policy formulation, our results show that monetary tightening in pegged exchange rate regimes can increase the probability of currency crises. Our interpretation of this result is that an interest rate hike can send a negative signal to investors by indicating weak fundamentals or panic at the monetary authority, therefore evoking more speculative attacks and finally leading to a currency crisis. Fifth, we also found some evidence that capital controls can mitigate the impacts of productivity shocks in pegged exchange rate regimes. Namely, if countries with pegged exchange rate regimes have capital controls, they can mitigate the effects of negative productivity shocks during currency crises. This is a new empirical finding that is not found in the existing literature. Although it is beyond the scope of this paper, a future study might investigate the mechanism for this role of capital control on productivity shocks. A possible interpretation is that capital controls can insulate the economy from volatile capital, and hence the resilience of the economy increases during the time when the country is hit by the shocks. Our last finding supports the conventional view that pegged exchange rate regimes under liberalized capital accounts increase the risk of currency crises. 


\section{Appendix: List of Countries}

\begin{tabular}{|c|c|}
\hline Argentina & Malaysia \\
\hline Armenia & Mexico \\
\hline Bolivia & Moldova \\
\hline Brazil & Morocco \\
\hline Bulgaria & Paraguay \\
\hline Burundi & Peru \\
\hline Cameroon & Philippines \\
\hline Central African Republic & Romania \\
\hline Chile & Russia \\
\hline China & Sierra Leone \\
\hline Colombia & South Africa \\
\hline Costa Rica & Thailand \\
\hline Cote d'Ivoire & Togo \\
\hline Dominican Republic & Tunisia \\
\hline Gabon & Ukraine \\
\hline India & Uruguay \\
\hline Indonesia & Venezuela \\
\hline
\end{tabular}




\section{References}

Agénor, P., J.S. Bhandari and R.P. Flood. (1992) Speculative Attacks and Models of Balance of Payments Crises. IMF Staff Papers 39: 357-394.

Aghion, P., P. Bacchetta and A. Banerjee. (2001) Currency Crises and Monetary Policy in an Economy with Credit Constraints. European Economic Review 45: 1121-1150.

Alvarez-Plata, P. and M. Schrooten. (2004) Misleading Indicators? The Argentinean Currency Crisis. Journal of Policy Modeling 26: 587-603.

Beckmann, D., L. Menkhoff and K. Sawischlewski. (2006) Robust Lessons about Practical Early Warning Systems. Journal of Policy Modeling 28: 163-193.

Berg, A. and C. Pattillo. (1999) Are Currency Crises Predictable? A Test. IMF Staff Papers 46: 107-138.

Caballero, R.J. and A. Krishnamurthy. (2001) International and Domestic Collateral Constraints in a Model of Emerging Market Crises. Journal of Monetary Economics 48: 513-548.

Céspedes, L.F., R. Chang and A. Velasco. (2004) Balance Sheets and Exchange Rate Policy. American Economic Review 94: 1183-1193.

Chang, R. and A. Velasco. (2001) A Model of Financial Crises in Emerging Markets. Quarterly Journal of Economics 116: 489-517.

Cheli, B. and P.D. Posta. (2007) Self-Fulfilling Currency Attacks with Biased Signals. Journal of Policy Modeling 29: 381-396. 
Combes, J., A. Minea and M. Sow. (2016) Crises and Exchange Rate Regimes: Time to Break Down the Bipolar View? Applied Economics 48: 4394-4409.

De Grauwe, P. (2000) Controls on Capital Flows. Journal of Policy Modeling 22: 391-405.

Dekle, R. and K.M. Kletzer. (2002) Domestic Bank Regulation and Financial Crises: Theory and Empirical Evidence from East Asia. In Preventing Currency Crises in Emerging Markets (S. Edwards and J.A. Frankel Eds). University of Chicago Press, Chicago.

Dooley, M.P. (2000) A Model of Crises in Emerging Markets. Economic Journal 110: 256-272.

Drazen, A. (2003) Interest Rate Defense Against Speculative Attack as a Signal: A Primer. In Managing Currency Crises in Emerging Markets (M.P. Dooley and J.A. Frankel Eds). University of Chicago Press, Chicago.

Eichengreen, B., A. Rose and C. Wyplosz. (1996) Contagious Currency Crises: First Tests. Scandinavian Journal of Economics 98: 463-484.

Erten, B. and J.A. Ocampo. (2017) Macroeconomic Effects of Capital Account Regulations. IMF Economic Review 65: 193-240.

Esaka, T. (2010) De Facto Exchange Rate Regimes and Currency Crises: Are Pegged Regimes with Capital Account Liberalization Really More Prone to Speculative Attacks? Journal of Banking \& Finance 34: 1109-1128.

Esaka, T. (2013) Evaluating the Effect of De Facto Pegs on Currency Crises. Journal of Policy Modeling 35: 943-963. 
Frankel, J.A. (2005) Mundell-Fleming Lecture: Contractionary Currency Crashes in Developing Countries. IMF Staff Papers 52: 149-192.

Frankel, J.A. and A.K. Rose. (1996) Currency Crashes in Emerging Markets: An Empirical Treatment. Journal of International Economics 41: 351-366.

Furceri, D., S. Guichard and E. Rusticelli. (2012) Episodes of Large Capital Inflows, Banking and Currency Crises, and Sudden Stops. International Finance 15: 1-35.

Ghosh, A.R., J.D. Ostry and M.S. Qureshi. (2015) Exchange Rate Management and Crisis Susceptibility: A Reassessment. IMF Economic Review 63: 238-276.

Ilzetzki E., C. Reinhart and K.S. Rogoff. (2017) Exchange Rate Arrangements Entering the 21st Century: Which Anchor Will Hold? NBER Working Paper No.23134.

Haile, F.D. and S. Pozo. (2006) Exchange Rate Regimes and Currency Crises: An Evaluation Using Extreme Value Theory. Review of International Economics 14: 554-570.

Kaminsky, G.L. and C.M. Reinhart. (1999) The Twin Crises: The Causes of Banking and Balance-of-Payments Problems. American Economic Review 89: 473-500.

Klein, M.W. and J.C. Shambaugh. (2008) The Dynamics of Exchange Rate Regimes: Fixes, Floats, and Flips. Journal of International Economics 75: 70-92.

Komulainen, T. and J. Lukkarila. (2003) What Drives Financial Crises in Emerging Markets? Emerging Markets Review 4: 248-272.

Kruger, M., P.N. Osakwe and J. Page. (2000) Fundamentals, Contagion and Currency Crises: An 
Empirical Analysis. Development Policy Review 18: 257-274.

Krugman, P. (1979) A Model of Balance-of-Payments Crises. Journal of Money, Credit and Banking 11: 311-325.

Kumar, M., U. Moorthy and W. Perraudin. (2003) Predicting Emerging Market Currency Crashes. Journal of Empirical Finance 10: 427-454.

Licchetta, M. (2011) Common Determinants of Currency Crises: The Role of External Balance Sheet Variables. International Journal of Finance and Economics 16: 237-255.

McKinnon, R.I. and H. Pill. (1997) Credible Economic Liberalizations and Overborrowing. American Economic Review 87: 189-193.

Mussa, M. (1999) Policies to Avoid or Ameliorate Financial Crises. Journal of Policy Modeling 21: $301-310$.

Nakatani, R. (2014) The Effects of Financial and Real Shocks, Structural Vulnerability and Monetary Policy on Exchange Rates from the Perspective of Currency Crises Models. UTokyo Price Project Working Paper Series No.061, Graduate School of Economics, University of Tokyo. http://www.price.e.u-tokyo.ac.jp/img/researchdata/pdf/p_wp061.pdf

Nakatani, R. (2016) Twin Banking and Currency Crises and Monetary Policy. Open Economies Review 27: 747-767.

Nakatani, R. (2017a) Structural Vulnerability and Resilience to Currency Crisis: Foreign Currency Debt versus Export. The North American Journal of Economics and Finance 42: 132-143. 
Nakatani, R. (2017b) The Effects of Productivity Shocks, Financial Shocks and Monetary Policy on Exchange Rates: An Application of the Currency Crisis Model and Implications for Emerging Market Crises. Emerging Markets Finance and Trade 53 (11): 2545-2561.

Nakatani, R. (2017c) External Adjustment in a Resource-Rich Economy: The Case of Papua New Guinea. IMF Working Paper, forthcoming.

Obstfeld, M. (1996) Models of Currency Crises with Self-Fulfilling Features. European Economic Review 40: 1037-1047.

Obstfeld, M., J.D. Ostry and M.S. Qureshi. (2017) A Tie That Binds: Revisiting the Trilemma in Emerging Market Economies. IMF Working Paper No.17/130.

Ozkan, F.G. and A. Sutherland. (1995) Policy Measures to Avoid a Currency Crisis. The Economic Journal 105: 510-519.

Radelet, S. and J.D. Sachs. (1998) The East Asian Financial Crisis: Diagnosis, Remedies, Prospects. Brookings Papers on Economic Activity 29: 1-74.

Robert, M.Y. (2005) The 1997-1998 Korean Crisis: Domestic or External Causes? Journal of Policy Modeling 27: 33-53.

Salvatore, D. (1999) Could the Financial Crisis in East Asia Have Been Predicted? Journal of Policy Modeling 21: 341-347.

Schneider, M. and A. Tornell. (2004) Balance Sheet Effects, Bailout Guarantees and Financial Crises. Review of Economic Studies 71: 883-913. 
Stiglitz, J.E. (1999) Lessons from East Asia. Journal of Policy Modeling 21: 311-330.

Zhao, Y., J. de Haan, B. Scholtens and H. Yang. (2014) Leading Indicators of Currency Crises: Are They the Same in Different Exchange Rate Regimes? Open Economies Review 25: 937-957. 